RhoAfl/fl mice. Additionally, RA-prone mice had higher expression of receptors to extracellular matrix proteins collagen ( $\alpha 2 \beta 2$ ) and fibronectin ( $\alpha 5 \beta 1)$ compared to control mice ( $p=0.016$ and $p=0.011$ resp) and to RA-protected mice (GLC Rac1fl/fl and GLC RhoAfl/fl, $p=0.0004$ and $p=0.011$, resp). In total, both the number of FoxP3+ CD 4 cells and the expression of a $5 \beta 1$ receptors on CD 4 cells correlated strongly with the synovitis score ( $r=0.72, p=0.0017$ and $r=0.59, p=0.012$, respectively).

GGTasel gene lays under the control of HOX proteins essential for cell homing. Importantly, HOX regulate the expression of integrins. Studying the expression of HoxA genes in spleen, we found that RA prone GLC and GLC Cdc42 mice tended to have lower expression of HoxA2 and higher expression of HoxA9 compared to RA-protected GLC Rac1 and GLC RhoA and to control mice. The Hoxa9/Hoxa2 ratio was significantly higher in RA prone mice compared to RA-protected mice $(p=0.0085)$ and control mice $(p=0.019)$. This ratio correlated with $a 5 \beta 1$ receptors $(r=0.55, p=0.0084)$, FOXP3+ CD4 cells ( $r=0.50, p=0.017)$, and the arthritis index $(r=0.50, p=0.033)$.

Conclusion: Taken together this study shows that Rho proteins play divergent role in development of arthritis. Activation of Rac1 and RhoA by GGTasel deletion changes the pattern of HOXA proteins and increases expression of integrin receptors, which facilitates leukocyte influx in the paw joints. Deletion of Rac1 and RhoA has RA-protective effect in GLC mice.

References:

[1] Khan, O.M., et al. J Clin Invest 121, 628 (2011).

[2] Akula, M.K., et al. Nat Commun 10, 3975 (2019).

Disclosure of Interests: None declared

DOI: 10.1136/annrheumdis-2020-eular.5564

\section{OP0335-PARE MODERNISATION OF PATIENT ORGANIZATION THROUGH ONLINE COURSES}

\section{N. Unesi' . ' Swedish Rheumatism Association, Stockholm, Sweden}

Background: A big and very crucial part of every membership organization is the continuing education of members and elected representatives in regional and local chapters.

Given the geographical long distances in Sweden, attending courses in person can be difficult, and expensive for the Swedish Rheumatism Association, the SRA. In 2019 the SRA developed a method to modernise our educational efforts by offering online courses to our elected representatives. Thus making it possible for anyone who has access to a computer to participate when it suits him or her. The courses can be done individually or in groups.

Objectives: The goal is to offer modern and cost effective ways to educate in matters selected by the SRA, and for elected representatives and members to be able to attend courses at any times.

Methods: The courses consists of films, texts and study exercises.

The staff of the SRA record films and make as much of the content themselves as possible. The content must be relaxed, easy to do and enhance the feeling of familiarity. Those who complete the courses should feel like they are in the same room as the lecturers.

Results: In 2019, the SRA completed two courses for elected representatives. The first course was on the matter of democratic structures at the annual general meeting of the SRA, and all decision making that applies for the SRA, for example, statutes, how to elect new board members and decide on an activity plan for the coming year. The course circled around these topics:

1. How do you write a motion and how do you send it to the annual meeting?

2. How do you prepare as a representative?

3. What happens at an annual general meeting?

4. How do you ask for the word and how do you argue for your cause?

5. How do you report from a general meeting to your local organization?

During the evaluation, the SRA received positive comments from those who attended. By the end of 2019, the SRA finished developing an online course on membership recruitment.

Conclusion: In 2020, the SRA plan to do three more online courses on the topic of systemic sclerosis, rheumatoid arthritis and fibromyalgia.

Online courses will not replace physical meetings, but offer a good alternative in the field of patient education.

Disclosure of Interests: None declared

DOI: 10.1136/annrheumdis-2020-eular.1018

\section{Improving work participation}

\section{OP0336-HPR \\ RISK FACTORS FOR PERSISTENCE AND DEVELOPMENT OF FREQUENT MUSCULOSKELETAL PAIN IN ADOLESCENT ATHLETES}

J. S Malmborg ${ }^{1}$, A. Bremander ${ }^{1,2,3}$, S. Bergman ${ }^{3,4}$, E. Haglund ${ }^{1,3}$, M. C. Olsson'1. ${ }^{1}$ Halmstad University, The Rydberg Laboratory for Applied Sciences, Halmstad, Sweden; ${ }^{2}$ University of Southern Denmark, Department of Regional Health Research, Odense, Denmark; ${ }^{3}$ Lund University, Department of Clinical Sciences Lund, Section of Rheumatology, Lund, Sweden; ${ }^{4}$ The Sahlgrenska Academy,
University of Gothenburg, Primary Health Care Unit, Department of Public Health and Community Medicine, Institute of Medicine, Gothenburg, Sweden

Background: Physical activity has a positive impact on health, but adolescent athletes often report musculoskeletal pain (MP) which is negative in the aspect of sustaining physical activity over time. There is a lack of longitudinal assessments of MP and potential risk factors, such as timing of physical maturation, in adolescent athletes. Objectives: To identify risk factors associated with the persistence or development of frequent MP at a 2-year follow-up in adolescent sport school students.

Methods: Fourteen-year-old sport school students $(n=233)$ were invited to participate in this 2-year longitudinal study. Self-reports of MP was assessed as frequency, distribution, and intensity, and health status by EQ-5D. Physical maturation was calculated by the Mirwald equation (height, weight, and sitting height) (1), and categorized as early ( $>1$ year), average ( \pm 1 year), or late $(<-1$ year). Students were grouped at baseline and follow-up into infrequent (never to monthly) or frequent (weekly to daily) MP groups. Logistic regression analysis was used to study associations between frequent MP at follow-up and baseline variables. Results: 131 students ( 79 boys and 52 girls) were included in the study. Development or persistence of frequent MP at follow-up $(n=61)$ was associated with being a girl, late physical maturation (only boys were categorized as late), non-contact sports participation, frequent MP at baseline, and reporting $\geq 2$ MP sites at baseline. Students with a better health status at baseline were less likely to belong to the frequent MP group at follow-up (Table).

Conclusion: Frequent MP is common in sport school students. MP in young athletes may become a future health problem and there is a need for recognition and interventions by coaches and health services to prevent MP from becoming persistent. References:

[1] Mirwald, R. L., Baxter-Jones, A. D., Bailey, D. A., \& Beunen, G. P. (2002). An assessment of maturity from anthropometric measurements. Med Sci Sports Exerc, 34(4), 689-694.

Table. Associations between background variables at baseline and frequent MP at follow-up based on crude logistic regression analysis controlling each variable for sex.

\begin{tabular}{|c|c|c|c|}
\hline \multirow[t]{2}{*}{ Baseline variables } & & \multicolumn{2}{|c|}{$\begin{array}{c}\text { Model } \\
\text { Infrequent MP vs. Frequent MP }\end{array}$} \\
\hline & & OR & (95\% Cl; p-value) \\
\hline Sex & $\begin{array}{l}\text { Boys } \\
\text { Girls }\end{array}$ & $\begin{array}{l}1.00 \\
2.76\end{array}$ & $(1.34-5.68 ; p<0.01)$ \\
\hline Physical maturation & $\begin{array}{c}\text { Average }( \pm 1 \text { year }) \\
\text { Early ( }>1 \text { year }) \\
\text { Late }(<-1 \text { year })\end{array}$ & $\begin{array}{l}1.00 \\
0.41 \\
3.83\end{array}$ & $\begin{array}{l}(0.05-3.65 ; p=0.42) \\
(1.13-12.95 ; p=0.03)\end{array}$ \\
\hline Sport categories & $\begin{array}{l}\text { Contact } \\
\text { Non-contact }\end{array}$ & $\begin{array}{l}1.00 \\
5.16\end{array}$ & $\begin{array}{l}(2.07-12.88 \\
p<0.001)\end{array}$ \\
\hline $\begin{array}{l}\text { MP groups } \\
\text { MP intensity last week (NRS }\end{array}$ & $\begin{array}{l}\text { Infrequent } \\
\text { Frequent }\end{array}$ & $\begin{array}{l}1.00 \\
2.74 \\
1.15\end{array}$ & $\begin{array}{l}(1.31-5.72 ; p<0.01) \\
(0.98-1.35 ; p=0.10)\end{array}$ \\
\hline $\begin{array}{l}0-10 \text {, best to worst) } \\
\text { Number of MP sites } \\
\text { EQ-5D (0.00-1.00, worst to best) }\end{array}$ & $\begin{array}{c}0 \\
1 \\
\geq 2\end{array}$ & $\begin{array}{l}1.00 \\
2.32 \\
2.87 \\
0.03\end{array}$ & $\begin{array}{l}(0.71-7.58 ; p=0.16) \\
(1.32-6.25 ; p<0.01) \\
(0.001-0.58 ; p=0.02)\end{array}$ \\
\hline
\end{tabular}

Disclosure of Interests: None declared

DOI: 10.1136/annrheumdis-2020-eular.1800

\section{New technologies in translational rheumatology}

\begin{tabular}{|l|l}
\hline OP0337 & DIFFERENTIAL METHYLATION OF PERIPHERAL \\
BLOOD ADAPTIVE IMMUNE CELLS IN INDIVIDUALS \\
AT HIGH RISK FOR RA AND WITH EARLY RA \\
COMPARED WITH CONTROLS IDENTIFIES PATHWAYS \\
IMPORTANT IN TRANSITION TO ARTHRITIS
\end{tabular}

R. $\mathrm{Ai}^{1}$, D. Boyle ${ }^{1}$, D. Hammaker ${ }^{1}$, K. Deane ${ }^{2}$, V. M. Holers ${ }^{2}$, A. Matti ${ }^{1}$, W. Robinson ${ }^{3}$,

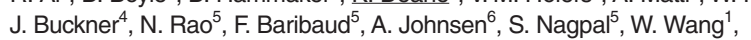
G. Firestein ${ }^{1} .{ }^{1}$ University of California, San Diego, La Jolla, United States of America; ${ }^{2}$ University of Colorado Denver, Aurora, United States of America; ${ }^{3}$ Stanford University, Stanford, United States of America; ${ }^{4}$ Benaroya Research Institute, Seattle, United States of America; 5 Janssen R\&D, Spring House, United States of America; ${ }^{6}$ Janssen $R \& D$, Spring House, United States of America

Background: The "Targeting Immune Responses for Prevention of RA" (TIP-RA) collaboration studies individuals at high risk for developing RA because of serum anti-citrullinated protein antibody positivity in absence of arthritis, and is focused on defining how they transition from at-risk to classifiable disease. One potential mechanism is through alterations in epigenetics patterns in adaptive immune cells. Objectives: Previous studies showed that DNA methylation patterns of early RA (ERA) synoviocytes differ from long-standing RA, suggesting that abnormal methylation occurs early in synovium and evolves over time. To extend these observations, we performed 